\title{
SALMONELLA SPP INVESTIGATION IN TRANSPORT BOXES OF DAY-OLD BIRDS
}

\author{
Fábio Tavares Zancan'; Angelo Berchieri Junior ${ }^{1 *}$; Sueli Aparecida Fernandes²; Nilce Maria Soares Queiroz Gama ${ }^{3}$ \\ ${ }^{1}$ Faculdade de Ciências Agrárias e Veterinárias, Universidade Estadual Paulista-UNESP, Jaboticacal, SP, Brasil. \\ ${ }^{2}$ Seção de Bacteriologia, Instituto Adolfo Lutz, São Paulo, SP, Brasil. ${ }^{3}$ Instituto Biológico, Bastos, SP, Brasil.
}

Submitted: December 06, 1998; Returned to authors for corrections: March 26, 1999; Approved: September 20, 2000

\begin{abstract}
The presence of Salmonella was investigated in transport boxes of newly hatched chicks in the moment they were received in the farms. 1,611 boxes, delivered to 15 farms (one broiler grand-parent farm, four broiler parent farms, two commercial broiler chick farms and seven laying hens farms) were tested. A total of 19 visits to these farms were done, and Salmonella was detected in ten of these visits. Salmonella Heidelberg was detected in boxes in five farms. $S$. Heidelberg and $S$. Mbandaka were simultaneously detected in one broiler breeder farm. Salmonella Enteritidis alone, $S$. Enteritidis and $S$. Mbandaka and $S$. Cerro alone were detected in three, one and one laying hens farms, respectively.
\end{abstract}

Key words: Salmonella, day-old bird, transport box

\section{INTRODUCTION}

Avian salmonellosis has been present in poultry flocks in some degree. Usually, traditional diseases, such as fowl typhoid and pullorum disease, are under control (14), although they have been seen in some countries in South and Central America, East European, Asia, Africa and even in Occidental Europe $(1,5)$. However, paratyphoid salmonellosis infections still are a great task to face. The infection of birds may provoke clinical disease and/or the birds become carriers of food-borne salmonellosis agents. Outbreaks of food-borne salmonellosis caused by Salmonella Enteritidis were noticed in several parts of the world in the last two decades associated with food prepared with poultry products $(1,13)$. Salmonella Enteritidis may have reached the farms by vertical transmission $(10,12$, 13). In the hatchery, cross-contamination among contaminated and non-contaminated eggs may occur (4) and can be found in samples collected inside the hatchery and inside transport boxes (6). In Brazil, the outbreaks provoked by Salmonella Enteritidis appeared after the outbreaks in Europe, USA and Japan (9, 17), probably because grand-parent flocks came from the areas where salmonellosis outbreak started. Nevertheless, there is no literature available to show the Salmonella status in day- old birds in Brazil. These information would be useful to clarify the importance of the vertical route of introduction of Salmonella to chicken flocks and also to show the importance of control programs. Thus, this work was carried out to investigate the presence of Salmonella in day-old birds, surveying the presence of the pathogen in the transport boxes. This approach permits the achievement of results without stressing the birds.

\section{MATERIALS AND METHODS}

1,611 boxes, delivered to 15 farms (one grand-parent farm, 6 parent farms, 6 laying hens farms and 2 commercial broiler farms) were tested. These boxes transported 161,086 day-old chicks. The sampling was done between March 1997 and March 1998.

The experimental procedure followed Wray and Davies (18) recommendations. The samples were taken from the internal wall and bottom of the boxes using one large gauze swab for each box. The swabs were moistened in PBS pH 7.4 before using. Five swabs were placed in a jar containing $100 \mathrm{~mL}$ selenite broth plus novobiocin. After overnight incubation at $42^{\circ} \mathrm{C}$, the broth was plated on brilliant green agar and Mac

\footnotetext{
* Corresponding author. Mailing address: Faculdade de Ciências Agrárias e Veterinárias, UNESP, Rodovia Carlos Tonanni, KM 5, CEP 14870-000, Jaboticabal, SP, Brasil. Fax:: (+5516) 322-4275. E-mail: berchier@fcav.unesp.br
} 
Conkey agar. Plates were incubated overnight at $42^{\circ} \mathrm{C}$. Typical colonies were inoculated in TSI agar and lysine broth, incubated overnight at $37^{\circ} \mathrm{C}$ and submitted to serotyping using polivalent sera against $\mathrm{O}$ and $\mathrm{H}$ Salmonella antigens. Isolates were sent to Adolfo Lutz Institute in São Paulo city, Brazil, for complete identification and serotyping.

\section{RESULTS}

The results in Tables 1 and 2 are related to broiler production and laying hens, respectively. Some farms were visited twice. According to Table 1, Salmonella was found in five out of nine samplings of boxes of day-old chickens for broiler production. All five positive samples were from parent flock farms. Salmonella Heidelberg was isolated in all of them, besides $S$. Mandaka which was isolated in one. The results of the search in laying hens farms (Table 2) indicated that 5 out 10 farms were Salmonella positive. Three farms were $S$. Enteritidis positive. $S$. Mbandaka was isolated in one farm and $S$. Cerro in another one.

\section{DISCUSSION}

The epidemiology of avian salmonellosis is very complex. Salmonella may reach a poultry flock through several ways, including vertical transmission. Contamination of birds in the beginning of life is more difficult to control because newly hatched chicks are very susceptible and may excrete salmonellae in high amount and for long periods $(2,16)$. Multiple age flocks and environmental factors, including rodents, play an important role in keeping flocks infected indefinitely $(7,8)$. Salmonella organisms spread out easily among eggs still in the hatchery and among birds later $(4,6)$. In the present work, Salmonella serotypes were found in some boxes delivered in 5 parent flocks farms for broiler production and in 5 flocks of laying hens farms. In farm II (Table 1), Salmonella Heidelberg was isolated from 10 out of 198 inspected boxes. One week later this serotype was found in the feces collected inside the same house and also in several points far from the initial point of detection (non-published data). The infection of young birds can result in poultry meat and egg containing Salmonella organisms (10,

Table 1. Presence of Salmonella in transport boxes of day-old chickens for broiler production

\begin{tabular}{|c|c|c|c|c|}
\hline \multirow{2}{*}{$\begin{array}{c}\text { Farm } \\
\text { Number }\end{array}$} & \multirow{2}{*}{ Activity } & \multicolumn{2}{|c|}{ Quantity examined of } & \multirow{2}{*}{ Result } \\
\hline & & boxes & Birds & \\
\hline I & Breeding & 80 & 8,000 & \\
\hline II & Breeding & 198 & 19,800 & Salmonella Heidelberg \\
\hline II & Breeding & 91 & 9,100 & Salmonella Heidelberg \\
\hline III & Breeding & 95 & 9,488 & Salmonella Heidelberg \\
\hline III & Breeding & 107 & 10,650 & Salmonella Heidelberg \\
\hline IV & Breeding & 160 & 16,000 & Salmonella Heidelberg \\
\hline & & & & Salmonella Mbandaka \\
\hline $\mathrm{V}$ & Breeding & 96 & 9,600 & \\
\hline VI & Broiler & 1 & 100 & \\
\hline VII & Broiler & 16 & 1,608 & \\
\hline TOTAL & & 844 & 84,346 & \\
\hline
\end{tabular}

Table 2. Presence of Salmonella in transport boxes of day-old laying hens

\begin{tabular}{|c|c|c|c|}
\hline \multirow{2}{*}{$\begin{array}{c}\text { Farm } \\
\text { Number }\end{array}$} & \multicolumn{2}{|c|}{ Quantity examined of } & \multirow{2}{*}{ Result } \\
\hline & Boxes & birds & \\
\hline I & 62 & 6220 & \\
\hline II & 6 & 600 & \\
\hline III & 70 & 7000 & \\
\hline IV & 63 & 6320 & \\
\hline V & 65 & 6500 & Salmonella Enteritidis \\
\hline VI & 156 & 15600 & Salmonella Enteritidis \\
\hline VI & 28 & 2800 & $\begin{array}{l}\text { Salmonella } \text { Enteritidis } \\
\text { Salmonella } \text { Mbandaka }\end{array}$ \\
\hline VII & 27 & 2700 & Salmonella Cerro \\
\hline VIII & 225 & 25000 & \\
\hline TOTAL & 767 & 76740 & \\
\hline
\end{tabular}


$11,12)$. Thus, the early detection is essential to start a control program. The increase of food-borne salmonellosis due to Salmonella Enteritidis was associated with egg and food containing raw egg (17), although recent work done by Silva et al. (15) has shown that this serotype is also very common in broiler carcasses. The results indicate that, despite the efforts to control Salmonella in poultry farms, they may still become contaminated through the vertical route by day-old birds that are purchased in countries where outbreaks of salmonellosis were noticed (13). In addition, the lack of a good approach to inspect imported day-old breed lines might be responsible for the introduction of Salmonella in Brazilian flocks of chickens. In spite of not being compared to the usual sampling procedure suggested for inspection of imported birds, the chance to find Salmonella using the sampling method employed in this study is higher since all transport boxes were tested. To reduce costs and labor, five swabs were put together for enrichment. Although partial examination may be satisfactory statistically, full examination may be more successful when the frequency of Salmonella is not high, as can happen in day-old breeder flocks. Cross-contamination among day-old birds is very easy. It starts during hatching (4) and Salmonella organisms can be found in hatchery fluff and meconium (3). Thus, transport boxes could be suitable to search the organism, without bothering the birds. Albeit further studies are necessary, this sampling methodology looks promising since Salmonella organisms were isolated in around $50 \%$ of the farms. Nowadays, Salmonella Mbandaka, $S$. Cerro and $S$. Heidelberg are not as common as $S$. Enteritidis, however they were also detected in human beings (17) and in birds (9). The strain of $S$. Enteritidis presented atypical biochemical behavior in TSI agar. This strain produced very little or almost none $\mathrm{H}_{2} \mathrm{~S}$. Based on the findings of the present work, day-old birds arrived to farms already contaminated with Salmonella and the examination of the transport boxes is a useful procedure to detect this contamination.

\section{ACKNOWLEDGEMENTS}

The authors wish to acknowledge Mr. Antonio José dos Santos and Mrs. Aparecida Rodrigues Batista for assistance in various ways. The authors also thank $\mathrm{CNPq}$ and FAPESP for financial support.

\section{RESUMO}

\section{Salmonella spp em caixas de transporte de pintos de um dia de idade}

Foram examinadas caixas de transporte de pintos de um dia com o objetivo de investigar a presença de Salmonella no momento em que chegaram à granja. 1611 caixas foram amostradas em 15 propriedades, sendo uma granja de avós, quatro granjas de matrizes, duas de frangos de corte e seis de aves de postura comercial. Foram feitas 19 visitas a essas granjas e Salmonella foi encontrada em 10 delas. Salmonella Heidelberg foi encontrada em caixas de cinco granjas, $S$. Heidelberg e $S$. Mbandaka em caixa de uma granja de matriz. $S$. Enteritidis somente, $S$. Enteritidis e $S$. Mbandaka simultaneamente, e $S$. Cerro somente, foram detectadas em caixas de três, uma e uma granjas de postura comercial, respectivamente.

Palavras-chave: Salmonella, aves de um dia de vida, caixas de transporte.

\section{REFERENCES}

1. Barrow, P.A. Salmonella control-past, present and future. Avian Pathol.,22: 651-669, 1993.

2. Barrow, P.; Simpson, J.M.; Lovell, M.A. Intestinal colonization in the chicken by food- poisoning Salmonella serotypes: microbial characteristics associated with faecal excretion. Avian Pathol., 17: 571-588, 1988.

3. Bhathia, T.R.S.; McNabb, G.D. Dissemination of Salmonella in BroilerChicken Operations, Manitoba - Canada, Avian Dis., 24: p.616-624, 1980.

4. Cason, J.A.; Cox, N.A.; Bailey, J.S. Transmission of Salmonella typhimurium during hatching of broiler chicks. Avian Dis.,38: 583-588, 1994.

5. Christensen, J.P.; Skov, M.N.; Hinz, K.H.; Bisgaard, M. Salmonella enterica serovar gallinarum biovar gallinarum in layers: epidemiological investigation of a recent outbreak in Denmark. Avian Pathol., 23: 489-501, 1994.

6. Cox, N.A.; Bailey, J.S.; Mauldin, J.M.; Blakenship, L.C. Presence and impact of Salmonella contamination in commercial broiler hatcheries. Poult. Sci., 69:.1606-1609, 1990.

7. Davies, R.H.; Wray, C. Observations on disinfection regimens used on Salmonella enteritidis infected poultry units. Poult. Sci., 74: 638-647, 1995.

8. Gast, R.K. Paratyphoid infections. In: Calnek, B.W.; Barnes, H.J.; Reid, W.M.; Yoder Jr., H.W (eds). Diseases of Poultry. 10 ed. Ames, Iowa, USA, 1997, p. 97-129.

9. Hofer, E.; Silva Filho, S.J.; Reis, E.M.F. Prevalência de sorovares de Salmonella isolados de aves no Brasil. Pesq.Vet. Bras., 17: 55-62, 1997.

10. Lister, S.A. Salmonella enteritidis infection in broilers and broiler breeders. Vet. Rec., 123 (13): 350, 1988.

11. McIlroy, S.G.; McCraken, R.M. The current status of the Salmonella enteritidis control programe in the United Kingdom. Annual Meeting of the US Animal Health Association, London, 1990, p.450-462.

12. O'Brien,J.D.P. Salmonella enteritidis infection in broiler chickens. Vet.Rec., 122: 214, 1988.

13. Rodrigue, D.C.; Tauxe, R.V.; Rowe, B. International increase in Salmonella enteritidis: A new pandemic? Epidemiol. Infect.,105: 21-27, 1990.

14. Shivaphrasad, H.L. Pullorum Disease and Fowl Typhoid. In: Calnek, B.W.; Barnes, H.J.; Reid, W.M.; Yoder Jr., H.W (eds). Diseases of Poultry. 10" ed. Ames, Iowa, USA, 1997. p. 82- 121.

15. Silva, D.M. Pesquisa de Salmonella em carcaças de frango congeladas utilizando diferentes meios de cultivo para o isolamento e avaliação de sensibilidade a agentes antimicrobianos. Jaboticabal-SP, 1998, 59 p. (Mestrado. Dissertação. Faculdade de Ciências Agrárias e Veterinárias UNESP).

16. Smith, H.W.; Tucker, J.F. The virulence of Salmonella strains for chicken; their excretion by infected chickens. J.Hyg., 84: 479-488, 1980.

17. Tavechio, A.T.; Fernandes, S.A.; Neves, B.C.; Dias, A.M.G.; Irino, K Changing patterns of Salmonella serovar: increase of Salmonella enteritidis in São Paulo. Rev.Inst. Med. Trop., 38: 315-322, 1996.

18. Wray,C.; Davies, R.H. Guideline on Detection and Monitoring of Salmonella infected Poutry Flocks with particular reference to Salmonella enteritidis, Graz, Austria: WHO, 1994, p.48. 